https://doi.org/10.11646/zootaxa.4363.3.7

http://zoobank.org/urn:lsid:zoobank.org:pub:9C8E62E5-60D9-45FA-818A-CF78304FC52C

\title{
Resurgence of a forgotten Southern Brazil endemic species: taxonomic position, redescription, and spatio-temporal distribution of Porosagrotis carolia Schaus, 1929 (Lepidoptera: Noctuidae: Noctuinae)
}

\author{
FERNANDO M. S. DIAS ${ }^{1,4}$, ALEXANDRE SPECHT ${ }^{2}$, GERMAN SAN BLAS ${ }^{3}$, \\ MIRNA M. CASAGRANDE ${ }^{1} \&$ OLAF H. H. MIELKE ${ }^{1}$ \\ ${ }^{1}$ Laboratório de Estudos de Lepidoptera Neotropical, Departamento de Zoologia, Universidade Federal do Paraná, P.O. Box 19.020, \\ 81.531-980,Curitiba,Brazil.E-mail:fernandomsdias@yahoo.com.br; mibras@ufpr.br; omhesp@ufpr.br \\ ${ }^{2}$ Embrapa Cerrados, Rodovia BR 020, Km 18, P.O. Box 08223, 73.310-970 Brasília, Brazil. \\ E-mail: alexandre.specht@embrapa.br \\ ${ }^{3}$ CONICET - Facultad de Ciencias Exactas y Naturales, Universidad Nacional de La Pampa, RN35 km 335, P.O.Box 6300, Santa \\ Rosa, Argentina. E-mail: gsanblas@exactas.unlpam.edu.ar \\ ${ }^{4}$ Corresponding author
}

\begin{abstract}
The taxonomy of the hitherto unplaced taxon Porosagrotis carolia Schaus, 1929 is evaluated and the name is taken out of taxonomic limbo and combined with Feltia Walker, 1856. Feltia carolia comb. nov., described from a single female specimen, is redescribed, including the first description of the male. Head, thorax and its appendages, and male and female genitalia are illustrated through photographs and line drawings; photographs of the holotype and a distribution map for the species is provided. Additionally, the spatio-temporal occurrence of the species in Rio Grande do Sul was assessed by monthly standardized samplings with light traps from January of 1998 to December of 1999 in ten different physiographical zones of the state. Our results suggest that F. carolia comb. nov. is univoltine and goes through prepupal and pupal estival diapauses. The assessment of the distribution of the species, based on the standardized samplings and specimens deposited in entomological collections, suggests that F. carolia comb. nov. is restricted to the southern Brazilian Campos, a mostly neglected environment discontinuously distributed in mountainous plateaus of the southern Mata Atlântica biome.
\end{abstract}

Key words: cutworm, Owlet moth, Noctuini, Agrotina, Feltia, Agrotis

\section{Introduction}

The enigmatic agrotine moth Porosagrotis carolia Schaus, 1929 was described based on a single female specimen from the state of Santa Catarina, Brazil, and almost completely ignored since then. The genus Porosagrotis, described by Smith (1890) (type species: Agrotis muraenula Grote \& Robinson, 1868, by original designation) to include twelve Nearctic species, was subsequently synonymized with the large and cosmopolitan genus Agrotis Ochsenheimer, 1816. Poole (1989) acknowledged the above cited synonymization but did not include $P$. carolia in Agrotis or in any other genus, leaving the name in a taxonomic limbo (as "Porosagrotis of authors"). Until recently, Agrotis served as a catch-all genus to lump species of Agrotini with characters as strong tibial setae, frons tubercle, and granular-skinned larvae. Most of these species are currently included in Agrotis, Euxoa Hübner, [1821], or Feltia Walker, 1856, forming a supposedly monophyletic group supported by the presence of a median diverticulum in the vesica (secondarily lost in some species), the very short or absent epicranial suture in the larvae, and by the large and coarse granules on the skin of the larvae (Lafontaine \& Fibiger 2004). Lafontaine (2004), reviewing the agrotine Nearctic fauna, recognized that Euxoa could be positively distinguished by characters of the male and female genitalia, but Agrotis and Feltia are harder to distinguish and continued to be confused. Lafontaine (2004) diagnosed both genera, further recognizing in Feltia two species groups: the Nearctic "subgothica-group" 
and the mostly Neotropical "subterranea-group." Several Neotropical species formerly in Agrotis where combined with Feltia in the "subterranea-group." This species group is somewhat transitional between other Feltia and Agrotis, since both lack cornuti and diverticula in the vesica, but species of the "subterranea-group" can be distinguished from Agrotis by the lack of a spiny sub-basal bar and a sclerotized band on the vesica, by the longer ampulla and clavus, and by the doubly bi-serrate or doubly bi-fasciculate antenna (Lafontaine \& Fibiger 2004). Nevertheless, some of these characters are secondarily modified in some species of the "subterranea-group"; for example, Lafontaine (2004) includes in this group F. williamsi (Schaus, 1923), a species with broadly bipectinate antenna.

The taxonomy and phylogeny of the Neotropical species of Agrotis was recently reviewed by San Blas (2014, 2015). San Blas (2014) proposed several new combinations and included several more Neotropical species formerly in Agrotis in the "subterranea-group" of Feltia, providing a new diagnosis to the group; the phylogenetic study carried out by the same author (San Blas 2015) recognized species of the "subterranea-group" as a distinct lineage possibly worthy of generic status. Nevertheless, $P$. carolia was not included or mentioned in neither the revision nor the phylogenetic analysis, even though Porosagrotis was then (and still is) considered a subjective synonym of Agrotis, and that the species was informally (and unintentionally) newly combined with that genus by Specht and Corseuil (2002). The last citations of P. carolia in the literature were given by Piovesan et al. (2014) and Orlandin et al. (2016) in compilations of the Lepidoptera fauna of the Santa Catarina state, referring only to the original description (and misleadingly reviving Porosagrotis).

In view of the above cited issues concerning the classification of the agrotine moths, this paper aims to review and redescribe the neglected taxon $P$. carolia, including its spatio-temporal distribution, the first description of the male, and, based on the morphology of males and females, to bring out the name from the limbo in which it is since Poole's (1989) catalogue.

\section{Material and methods}

All examined studied specimens are deposited in the following collections: CLAM: Coleção Alfred Moser, São Leopoldo, Brazil; MCTP: Museu de Ciência e Tecnologia da Pontifícia Universidade Católica do Rio Grande do Sul, Porto Alegre, Brazil; and USNM: National Museum of Natural History, Washington, D.C., USA. Dissected specimens (marked with an asterisk in the Examined Material section) had their body parts detached and soaked in $10 \%$ potassium hydroxide solution in a test tube heated in a bain-marie in a beaker for approximately 5-10 minutes; all dissections were kept in glycerin in vials with the dissected specimen. The abdomen was further dissected and the genitalia removed. The genitalia were examined under a stereoscopic microscope, and illustrations were prepared with aid of a camera lucida and digital photographic camera attached to the stereoscopic microscope, by focus stacking system. In the illustrations full lines represent sclerotized structures, thinner full lines membranous structures, dashed lines structures visible through transparent body parts, and dotted lines areas of different sclerotization. The valva were flattened for examination. As males and females are generally similar, the diagnosis and the description were based on males except for features that are sexually dimorphic (e.g. antenna). The terminology of Lafontaine (2004) is employed for structures of the genitalia and areas and elements of wing pattern. Adults are illustrated at two times the life size, but scale bars are provided for all structures. Higher level taxonomy follows Poole (1989) and Lafontaine (2004); genus- and species-level taxonomy follows San Blas (2014), including the diagnosis of the "subterranea-species group". Distribution maps were prepared in SimpleMappr (Shorthouse, 2010), extrapolated from the georeferenced labels of examined specimens.

The spatio-temporal distribution was evaluated by monthly samplings with light traps between January of 1998 and December of 1999, in sites representing ten of the eleven physiographic zones of the State of Rio Grande do Sul, Brazil (Arend 1990), namely (municipality and coordinates of sampling sites in parenthesis): Litoral (Mostardas, $31^{\circ} 02^{\prime} \mathrm{S}$; $50^{\circ} 57^{\prime} \mathrm{W}$ ), Missões (São Borja, $28^{\circ} 42^{\prime} \mathrm{S}$; $56^{\circ} 05^{\prime} \mathrm{W}$ ), Campanha (Santana do Livramento,

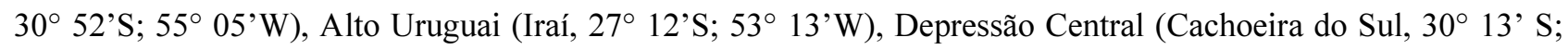
$52^{\circ} 56^{\prime} \mathrm{W}$ ), Serra do Sudeste (Piratini, $31^{\circ} 31^{\prime} \mathrm{S}$; $53^{\circ} 05^{\prime} \mathrm{W}$ ), Encosta do Sudeste (Camaquã, $30^{\circ} 45^{\prime} \mathrm{S}$; $51^{\circ} 52^{\prime} \mathrm{W}$ ), Campos de Cima da Serra (Lagoa Vermelha, $28^{\circ} 14^{\prime} \mathrm{S}$; $51^{\circ} 35^{\prime} \mathrm{W}$ ), Encosta Superior do Nordeste (Vila Maria, $28^{\circ}$ $25^{\prime} \mathrm{S}$; 52 $09^{\prime} \mathrm{W}$ ), Encosta Inferior do Nordeste (São Pedro da Serra, $29^{\circ} 25^{\prime} \mathrm{S} ; 51^{\circ} 28^{\prime} \mathrm{W}$ ); Planalto Médio was not sampled. Light traps of the "Pennsylvania" type (Frost 1957) were equipped with fluorescent ultraviolet lamps 
model F15 T12 LN, with wave lengths ranging from 290-450 um, peaking about 340 um. The traps were attached to plastic truncated inverted cones with $32 \mathrm{~cm}$ and $16 \mathrm{~cm}$ of upper and lower diameter, respectively, and the cones were attached to buckets with 31 of Ethanol 96 GL. Each site was sampled for one night, with two traps placed 2 $\mathrm{m}$ above the ground and at least $2 \mathrm{~km}$ apart, sampling continuously for about $12 \mathrm{~h}$ from sunset to sunrise. The samples were taken during the new moon, avoiding nights with heavy rain or temperatures below $12{ }^{\circ} \mathrm{C}$.

\section{Results and discussion}

\section{Feltia carolia (Schaus, 1912) comb. nov.}

(Figs 1-35)

Porosagrotis carolia Schaus, 1929, p. 47, pl. 2, Fig. 16. Type locality: Santa Catarina, Brazil; supposedly deposited at the USNM (see comments below).--Piovesan et al., 2014. p. 29.-Orlandin et al., 2016 p. 99.

Porosagrotis of authors [sic] carolia; Poole, 1989, pt. 2, p. 832, pt. 3, p. 1138.

Agrotis carolia; Specht \& Corseuil, 2002, p. 288.

Diagnosis. Feltia carolia comb. nov. (Figs 1-6) can be distinguished from all other Neotropical Feltia, by the following combination of characters: male with broadly bipectinate antenna, each rami up to four times as wide as the central shaft (Figs 10-11); patagium anteriorly with dark brown and posteriorly with lighter brown scales; tegula mostly creamy white, surrounded by light brown and brown scales and bordered medially by a dark brown line; mesothorax with a creamy white median spot (Fig. 14); forewing upper side with creamy white scales on Radial, $R_{1}, R_{2}, R_{3}$ and Cubital veins up to about the end of the discal cell, similar but less marked light brown scales on the basal half of $1 \mathrm{~A}+2 \mathrm{~A}$; discal cell mostly dark brown, with antemedial line and orbicular spot grayish brown, connected along the Radial vein and bordered by a thin light brown line; orbicular spot not reaching the Cubital vein; renifom spot brown and bordered by a thin light brown line, extending from the Radial to the Cubital vein and connected to the orbicular spot in some specimens (Fig. 15). Male genitalia with corona restricted to dorsal third of the apex of valve; valve widening apically; cornutus and diverticula absent, except for a small apical diverticulum (Figs 26-29).

Redescription. Head. (Figs 7-13, 18). Vertex brown and light brown; frons light brown and creamy white, tubercle naked, round, flat and slightly ridged, with a very small central bulge; compound eyes naked, mostly brown with dark brown blotches; male antenna about three fifths the length of the costal margin, scapus and pedicelus covered by light brown and creamy white scales, antennomers broadly bipectinate, ventrally naked, dorsally covered by light brown and creamy white scales and bristles, each rami up to four times the width of the central shaft, densely covered by fine setae and distally slightly clubbed; labial palpus first and second segments covered mostly by large brown and light brown scales with creamy white scales distally, third segment covered by brown, light brown and creamy white shorter scales, first and second segment thick and slightly curved, the latter twice the length of the former, inner area of first segment rough, with fine scales, third segment oblong, about $1 / 3$ the width and $2 / 3$ the length of the first segment, vom Rath organ reaching the half of the length of the third segment. Female as in male, but antenna filiform, ventrally naked, dorsally covered by light brown and creamy white scales.

Thorax. (Fig. 14). Patagium anteriorly with dark brown and posteriorly with light brown scales; tegula mostly creamy white, surrounded by light brown and brown and bordered medially by dark brown line; meso- and metathorax dorsally mostly light brown and brown, with a creamy white median spot; thorax ventrally with brown, light brown and creamy white scales. Female as in male.

Legs. (Figs 19-23). Mostly grayish brown, speckled with darker and lighter scales; foreleg coxa thick, strongly developed; trochanter small and curved; femur about one and a half times longer than the coxa, smooth; tibia dorso-ventrally flattened, about half the length of the femur, wider in anterior view, with strong lateral and distal spines, epiphysis $2 / 3$ the length of the tibia; midleg femur slightly longer than the tibia, smooth; tibia wider distally; hindleg femur $2 / 3$ the length of the tibia, about the same size of the midleg femur, smooth; all femora, tibiae and tarsi with three somewhat regular rows of ventral spines, tibiae and first tarsomeres also with sparse additional outer spines; tarsal claws bifid. Female as in male. 

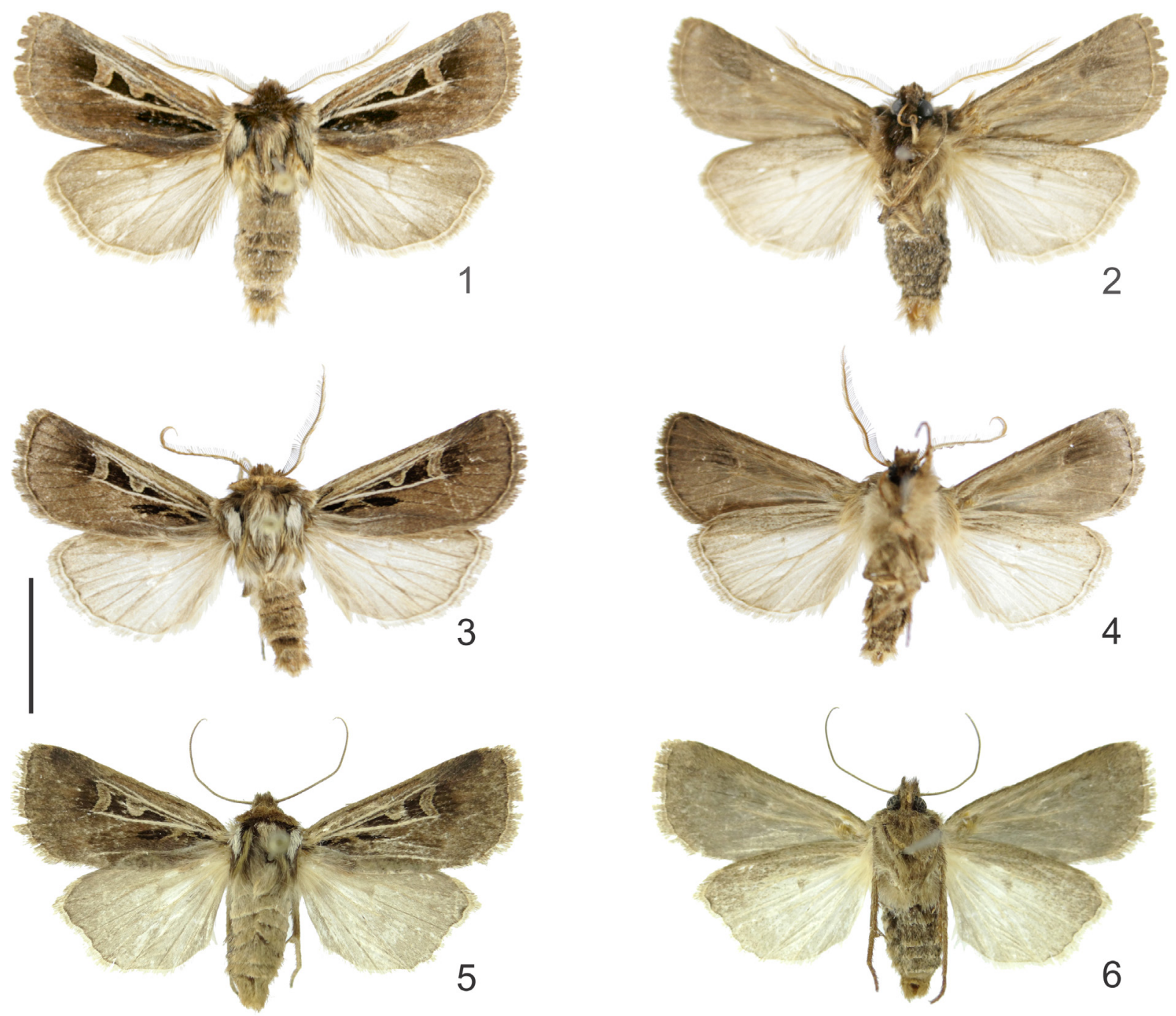

FIGURES 1-6. Feltia carolia (Schaus, 1929) comb. nov., dorsal and ventral habitus.1-2. Male, Lagoa Vermelha, Rio Grande do Sul, Brazil (MCTP 9536). 3-4 Male, Lagoa Vermelha, Rio Grande do Sul, Brazil (MCTP 9538). 5-6. Female, Cambará do Sul, Rio Grande do Sul, Brazil (CLAM 00021). Scale bar $=1 \mathrm{~cm}$.

Forewing size, shape and venation. (Figs 1-6, 15-17, 24-25). Average size of males $1.55 \mathrm{~cm}(1.5 \mathrm{~cm}-1.65$ $\mathrm{cm} ; \mathrm{n}=17)$ and females $1.65 \mathrm{~cm}(1.6 \mathrm{~cm}-1.7 \mathrm{~cm} ; \mathrm{n}=2)$ (holotype = "38 cm of wingspan" (Schaus 1929)); wing shape and venation similar to other agrotines.

Forewing, upperside. (Figs 1, 3, 5, 15). Ground color mostly grayish brown, subcostal band light brown from the base of the wing to about $R_{1}$ and brown from about $R_{1}$ to the apex; base of Sc dark brown; Radial and Cubital veins and the very bases of $R_{1}, R_{2}, R_{3}$ and $M_{3}$ creamy white; base of $1 A+2 A$ light brown; remainder veins dark brown; orbicular spot grayish brown, projected basally along the Radial vein and bordered by a thin light brown line; orbicular spot not reaching the Cubital vein; renifom spot grayish brown and bordered by a thin light brown line, extending from the Radial to the Cubital vein and connected to the orbicular spot in some specimens; remainder of the discal cell dark brown; area from the reniform spot to about the postmedial area dark brown; basal dash and claviform spot dark brown, with a light brown bowed marking between them reaching the Cubital vein; transversal lines indistinct; terminal line with dark brown chevrons; fringe grayish light brown to brown. Female as in male but usually darker.

Forewing, underside. (Figs 2, 4, 6, 16-17). Mostly grayish light brown, darker along the costal margin and the discal cell; terminal line with dark brown chevrons; males with a darker brown spot after the end of the discal cell; male retinaculum as a patch of densely packed scales on the Radial vein. Female as in male, but retinaculum as a patch of enlarged scales on the Cubital vein. 

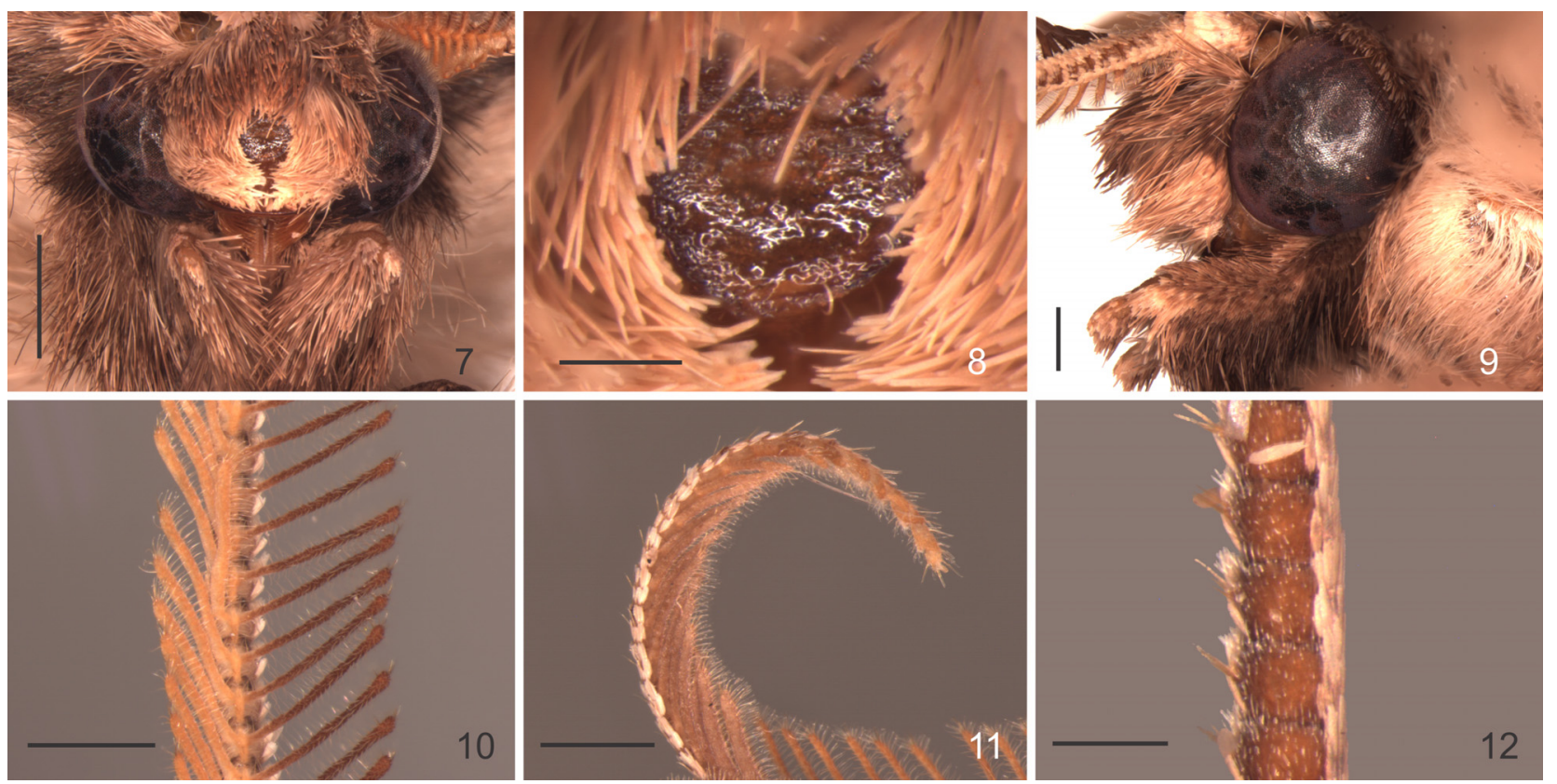

FIGURES 7-12. Feltia carolia (Schaus, 1929) comb. nov., head and appendages. 7. Head, anterior. 8. Frons tubercle, anterior. 9. Head, lateral. 10. Male antenna in its widest part, ventral. 11. Male antenna distal segments, lateral. 12. Female antenna, lateral. Scale bars: Fig. $7=1 \mathrm{~mm}$, Fig. $8=0.2 \mathrm{~mm}$, Figs $9-11=0.5 \mathrm{~mm}$, Fig. $12=0.2 \mathrm{~mm}$.

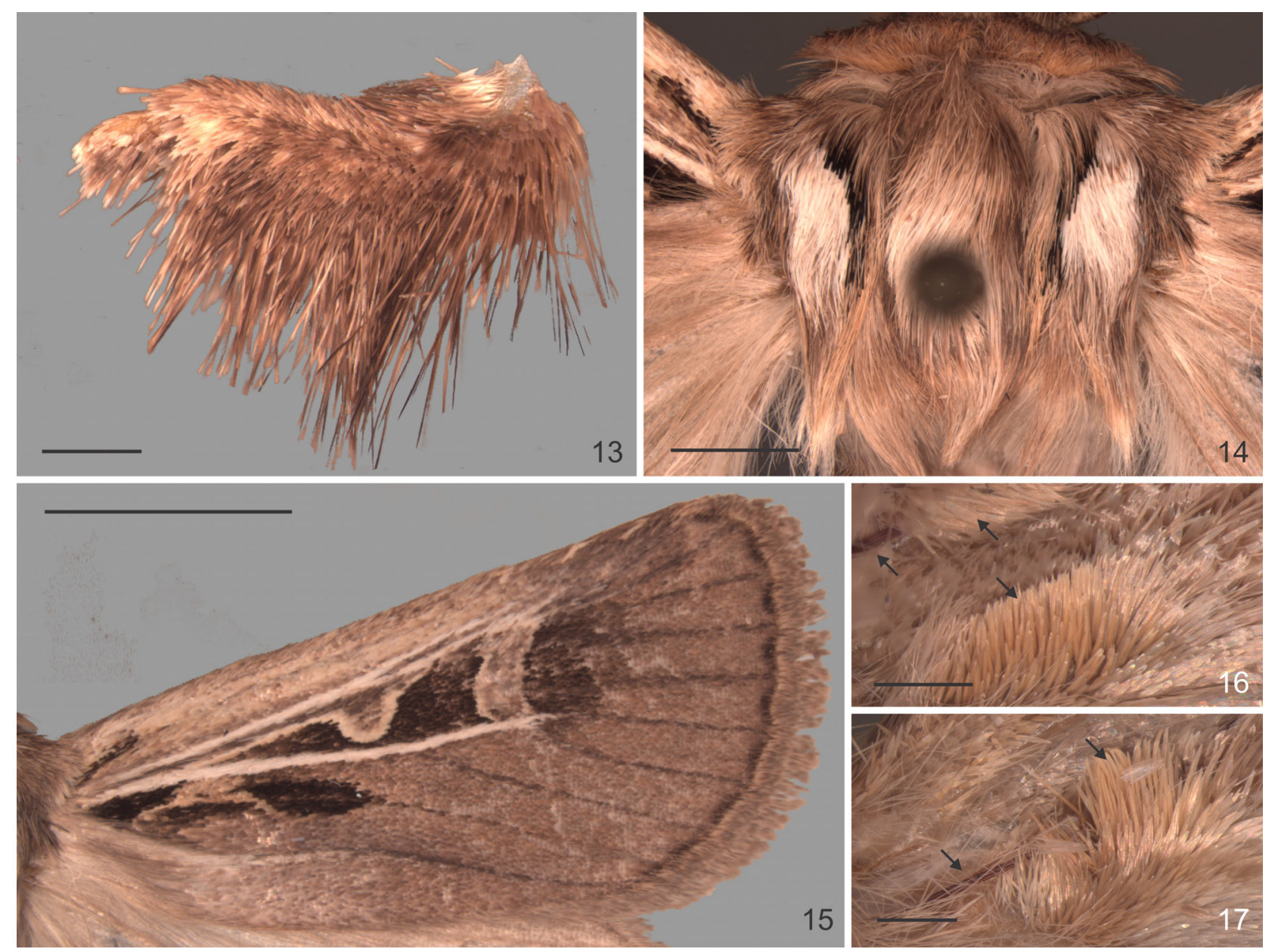

FIGURES 13-17. Feltia carolia (Schaus, 1929) comb. nov., labial palpus, thorax and appendages. 13. Labial palpus, lateral. 14. Thorax, dorsal. 15. Forewing, upper side. 16. Male wing coupling. 17. Female wing coupling. Arrows point out frenula, retinacula and patches of enlarged scales. Scale bars: Fig. $13=0.5 \mathrm{~mm}$, Fig. $14=2 \mathrm{~mm}$, Fig. $15=5 \mathrm{~mm}$, Figs. $16-17=0.5 \mathrm{~mm}$. 

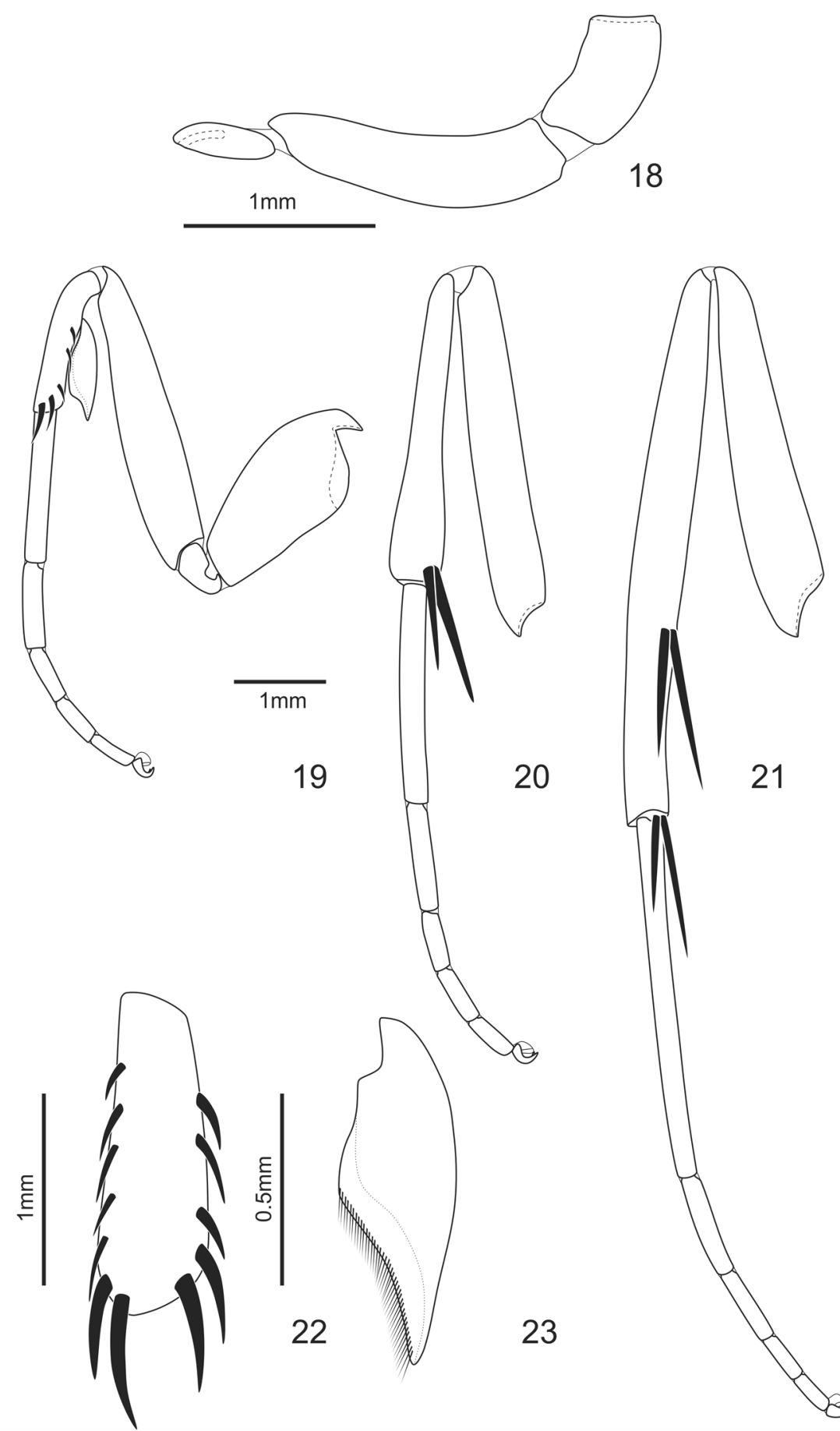

19

20

\section{1}

22

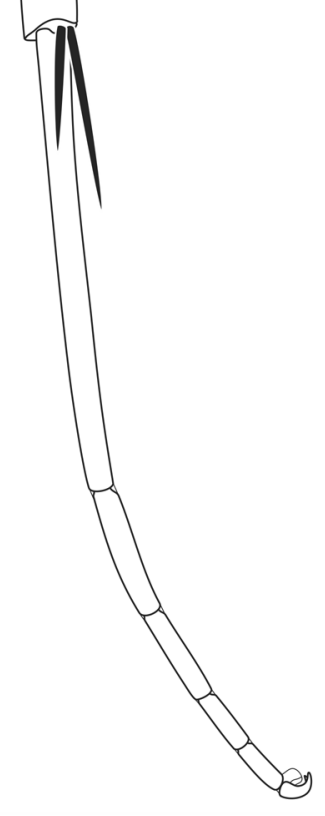

FIGURES 18-23. Feltia carolia (Schaus, 1929) comb. nov., labial palpus and legs. 18. Labial palpus, lateral. 19. Foreleg, lateral. 20. Mid leg, lateral. 21. Hind leg, lateral. 22. Foreleg tarsus, anterior. 23. Foreleg epiphysis, lateral.

Hind wing, upper side. (Figs 1, 3, 5). Wing shape and venation similar to other agrotines; mostly creamy white, with grayish light brown scales on the veins and along the costal, outer and inner margins, discal spot indistinct, fringe creamy white to grayish light brown. Female as in male but usually darker.

Hind wing, underside. (Figs 2, 4, 6, 16-17). Similar to the upper side, but with discal spot slightly distinct, grayish light brown; male frenulum formed by a single strong bristle. Female as in male, but frenulum formed by two stronger and one weaker bristle.

Abdomen. (Figs 1-6). Dorsally, laterally and ventrally grayish brown, speckled with darker and light scales, and with lighter scales on the posterior margin of each segment; male coremata and associated structures absent. Female as in male, but the abdomen is somewhat stouter and abruptly tapering at the last segments. 


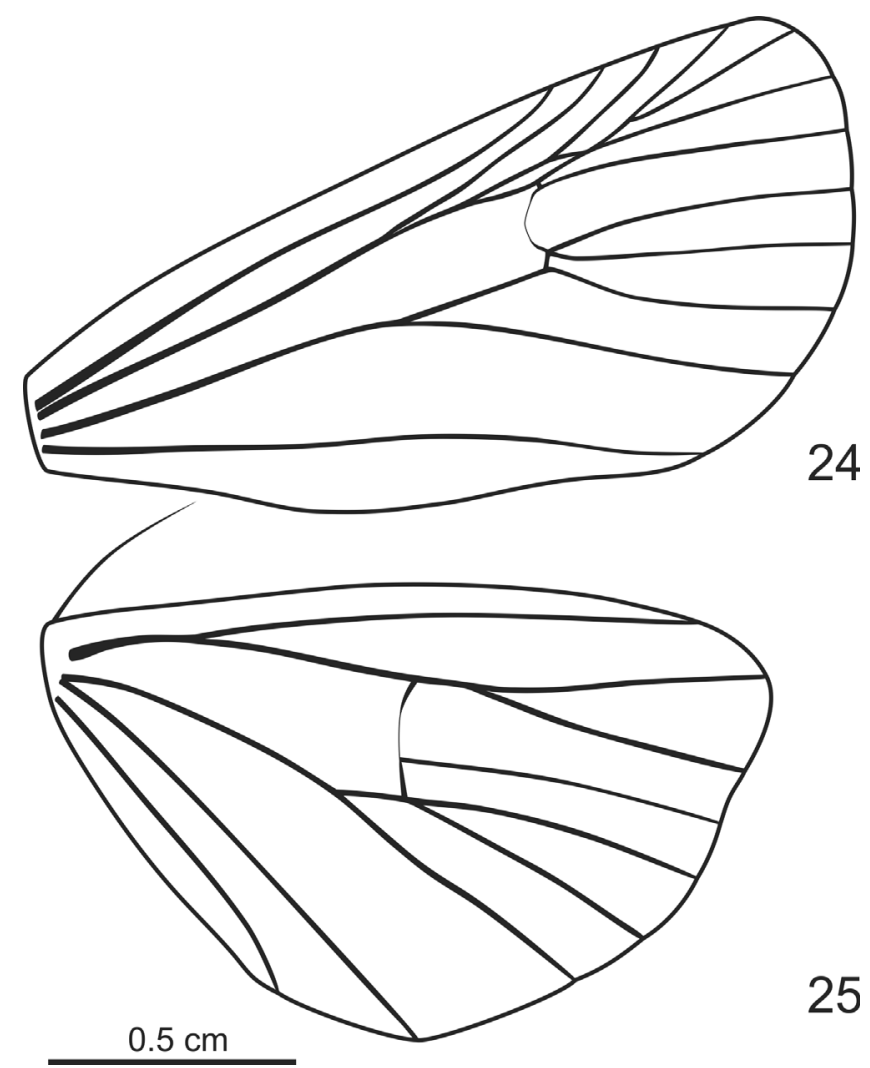

FIGURES 24-25. Feltia carolia (Schaus, 1929) comb. nov., male wing shape and venation.
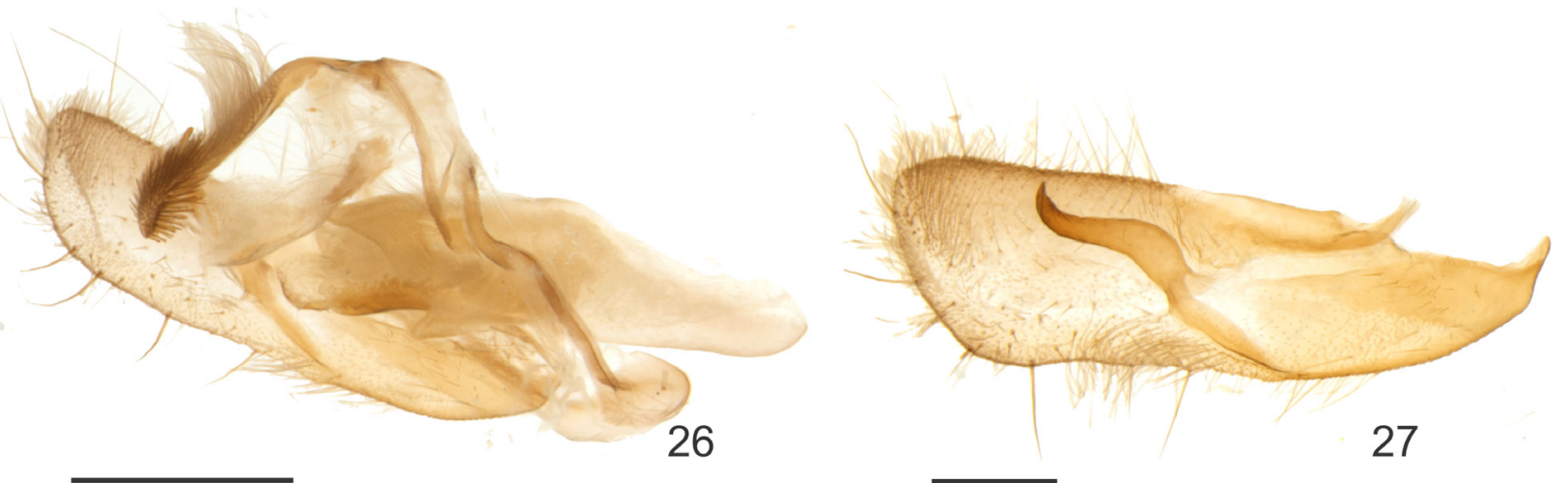

FIGURES 26-27. Feltia carolia (Schaus, 1929) comb. nov., male genitalia, lateral. 26. genitalia with right valva removed. 27. Valva. Scale bars: Fig. $26=1 \mathrm{~mm}$, Fig. $27=0.5 \mathrm{~mm}$.

Male genitalia. (Fig. 26-29). Tegumen strap-like, ventral arm enlarged, connecting to the dorsal arm of the saccus; saccus short, globose and posteriorly projected, dorsal arms thin and sinuous; uncus long and somewhat straight with dorsally curved scales, tapering distally to a point with thick posteriorly directed spines; anal tube (i.e. subscaphium) sclerotized ventrally; valva widening distally, sacculus and clavus weakly sclerotized; ampulla 1/3 the length of the valva, digitus absent; corona reduced only at the dorsal third of the valva; juxta (i.e. fultura inferior) sub-triangular, narrower close to the sacculus, widening dorsally; vesica of aedeagus everting ventrally but somewhat straight, swollen at the base, about four times the length of the aedeagus, distal third tapered, apical diverticulum small, other diverticula absent. 

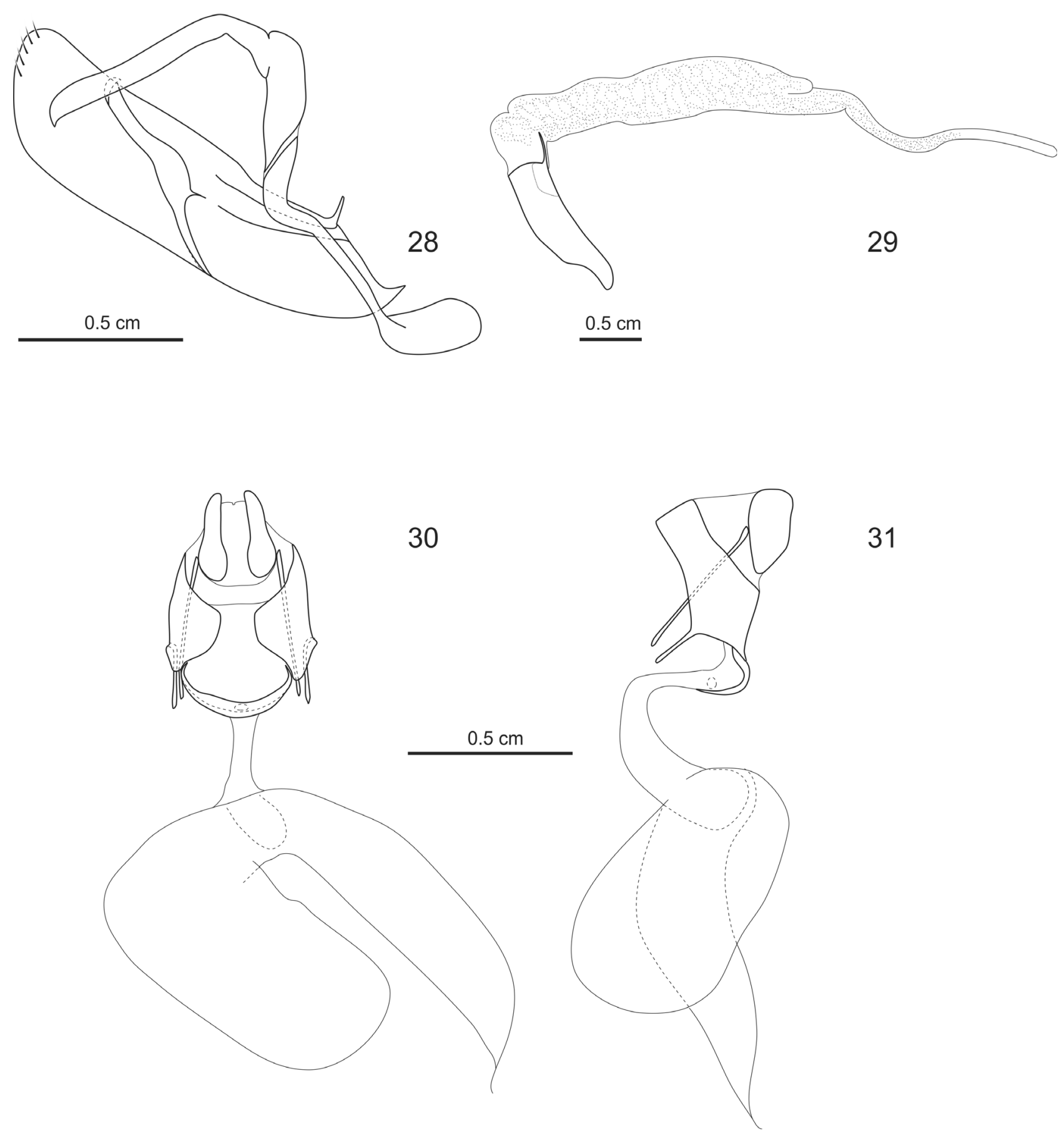

FIGURES 28-31 Feltia carolia (Schaus, 1929) comb. nov., male and female genitalia, lateral. 28-29. Male genitalia. 28. Male genitalia with aedeagus and right valva removed. 29. Aedeagus with vesica everted, posterior side up. 30-31. Female genitalia. 30. Ventral. 31. Lateral.

Female genitalia. (Figs 30-31). Lamella antevaginalis strap-like; lamella postvaginalis absent; abdominal segment VIII not fused ventrally, width about $1 / 3$ the length of the segment in lateral view, wider ventrally; apophysis anterioris on the ventral third of the abdominal segment VIII, in its widest area; apophysis posterioris long, about three times the length of the apophysis anterioris; papilla analis oblong; ostium bursae medial; ductus bursae thinner than the corpus bursae and the appendix bursae; corpus bursae rounded, about $2 / 3$ the length of the short and curved appendix bursae, signa absent; appendix bursae more or less cylindrical, abruptly tapering distally to the ductus seminalis. 

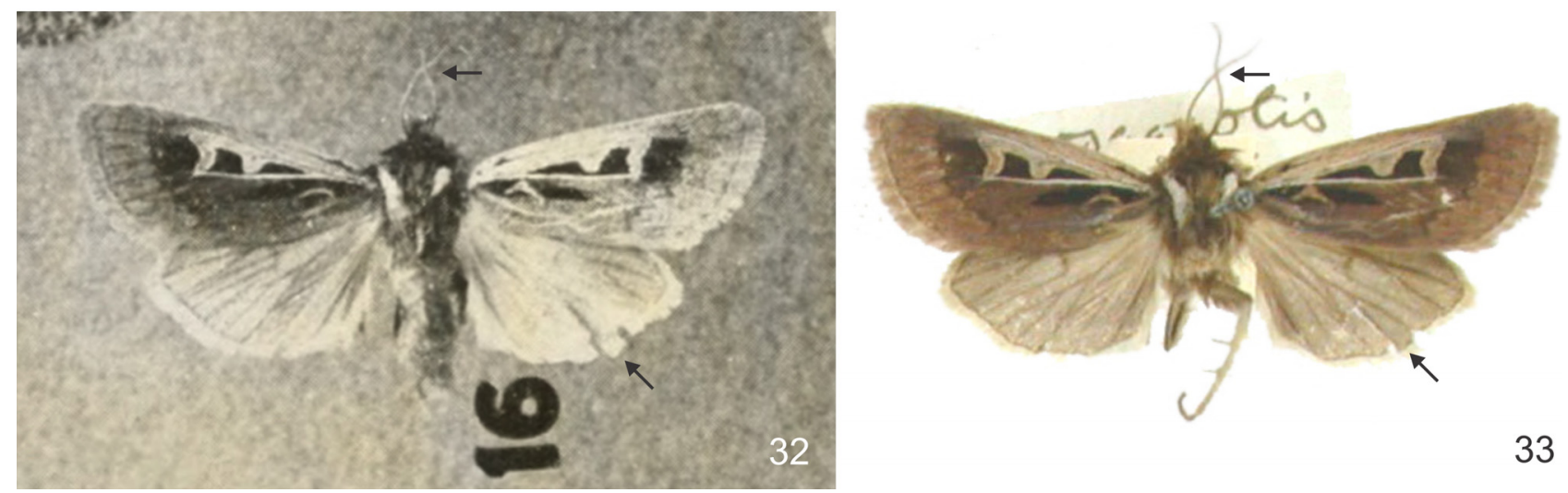

FIGURES 32-33. Holotype of Porosagrotis carolia Schaus, 1929. 32. Reproduction from Schaus' original description plates. 33. Holotype located by J. Bolling Sullivan (see text for details). Arrows point out features indicating that this is the same specimen illustrated by Schaus (1929).

Comments. Feltia carolia comb. nov. was described from a single female from Santa Catarina, from specimens donated by Mr. Edward Dukinfield Jones collected in various localities in southern and southeastern Brazil (Schaus 1929). The female holotype was collected in March, 1922, and was recorded in the catalog of the USNM under the number 33535 (Fig. 32). However, even though the USNM collection website claims that the holotype is deposited there (SI-USNM 2017), this specimen was not located in the type collection by Dr. Paul Goldstein, the current curator of Noctuidae of the USNM (P. Goldstein, pers. comm.). Dr. Donald Lafontaine, having examined and photographed all Noctuidae types at the USNM, notes that here is not even a spot for it in the type collection, suggesting that this specimen was never recognized as a holotype of F. carolia comb. nov. (J. D. Lafontaine, pers. comm.); the lack of specimens for examination is the likely reason why Poole (1989) chose not to assign Schaus' name to a genus. The holotype was located by Dr. J. Bolling Sullivan which, although correctly identified, was not promptly recognized as the holotype of F. carolia comb. nov. (J. B. Sullivan, pers. comm.) (Fig. 33). For that reason the collection where the specimen was located was not recorded at the time the picture was taken and unfortunately that information could not be retrieved. This female specimen agrees closely in pattern with the female specimen figured by Schaus in the original description (Schaus 1929: 47, pl. 2, Fig. 16), here figured. This specimen can be positively recognized as the holotype by the characteristic arrangement of the antenna and damage on the right hind wing (Figs 32-33). The specimen was subsequently dissected or lost its abdomen; if dissected, the whereabouts of the dissection is not known. The distinctive color pattern of the thorax and fore wing can positively identify the specimens from the nearby state of Rio Grande do Sul, Brazil, presented here, as belonging to the same species.

To our knowledge, no further citations or specimens were collected after the description of the species to the middle and late nineties, when several specimens were collected; some of these records were ultimately published by Specht \& Corseuil (2002) (although cited as "Agrotis carolia"). An additional single female specimen was located at the CLAM mixed with specimens tentatively identified as F. subterranea (Fabricius, 1794)-the most common species of Feltia occurring in Brazil. This specimen was captured in 2014 (Figs 5-6) by Dr. Alfred Moser, who collected moths extensively for several years in the presumed area of distribution of this species. Dr. Ceslau M. Biezanko, who collected in several localities of Rio Grande do Sul, Brazil, for several years never recorded or deposited in his collection specimens of this species (Specht et al. 2004). Several other Brazilian collections were visited, including some major collections such as the Coleção Entomológica Padre Jesus Santiago Moure, Universidade Federal do Paraná (DZUP), Museu de Zoologia da Universidade de São Paulo (MZUSP), Museu Nacional do Rio de Janeiro (MNRJ), Coleção Hubert Thöny (HT), and Coleção Vitor Osmar Becker (VOB), but no further specimens were located. 


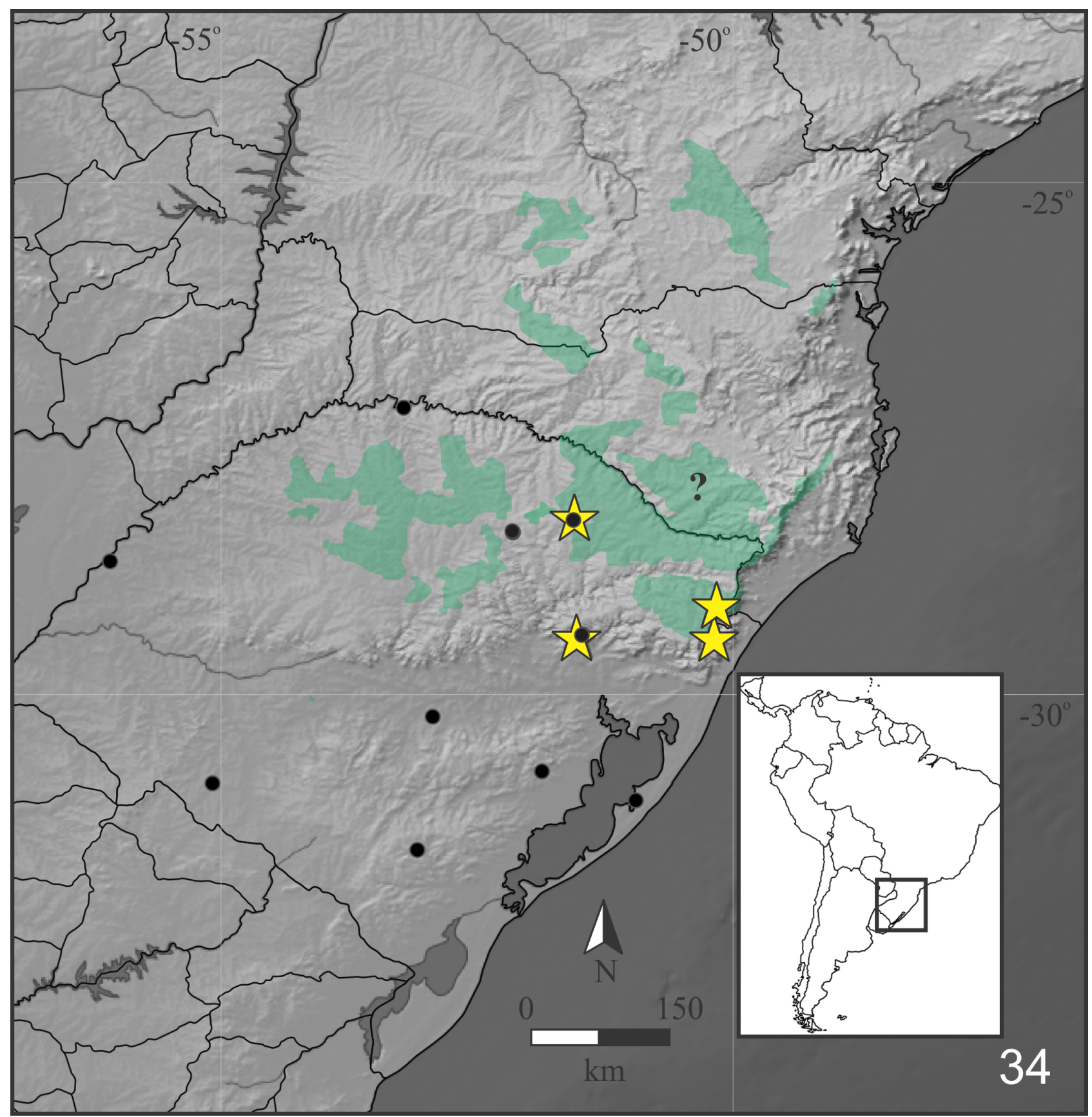

FIGURE 34. Feltia carolia (Schaus, 1929) comb. nov., spatial distribution. Black dots indicate localities of standardized samplings; yellow stars, the presence of F. carolia comb. nov., and the question mark, the state of the type locality; green shaded areas indicates roughly areas of southern Brazilian Campos, according to Overbeck et al. (2007).

Feltia carolia comb. nov. can be rapidly distinguished from other South American species of the genus by the strongly bipectinate antenna, only shared with F. chilensis (Hampson, 1903) and F. brachystria (Hampson, 1903). The former has the forewing with all the transversal lines differentiated, the creamy white scales on the Radial and Cubital veins are absent, in the male genitalia the ampulla is half as long as valva, and its distribution is restricted to Chile. Feltia brachystria can be distinguished from F. carolia comb. nov. by the darker forewing ground color, the presence of the transversal lines, and male genitalia with valve not widening distally. 


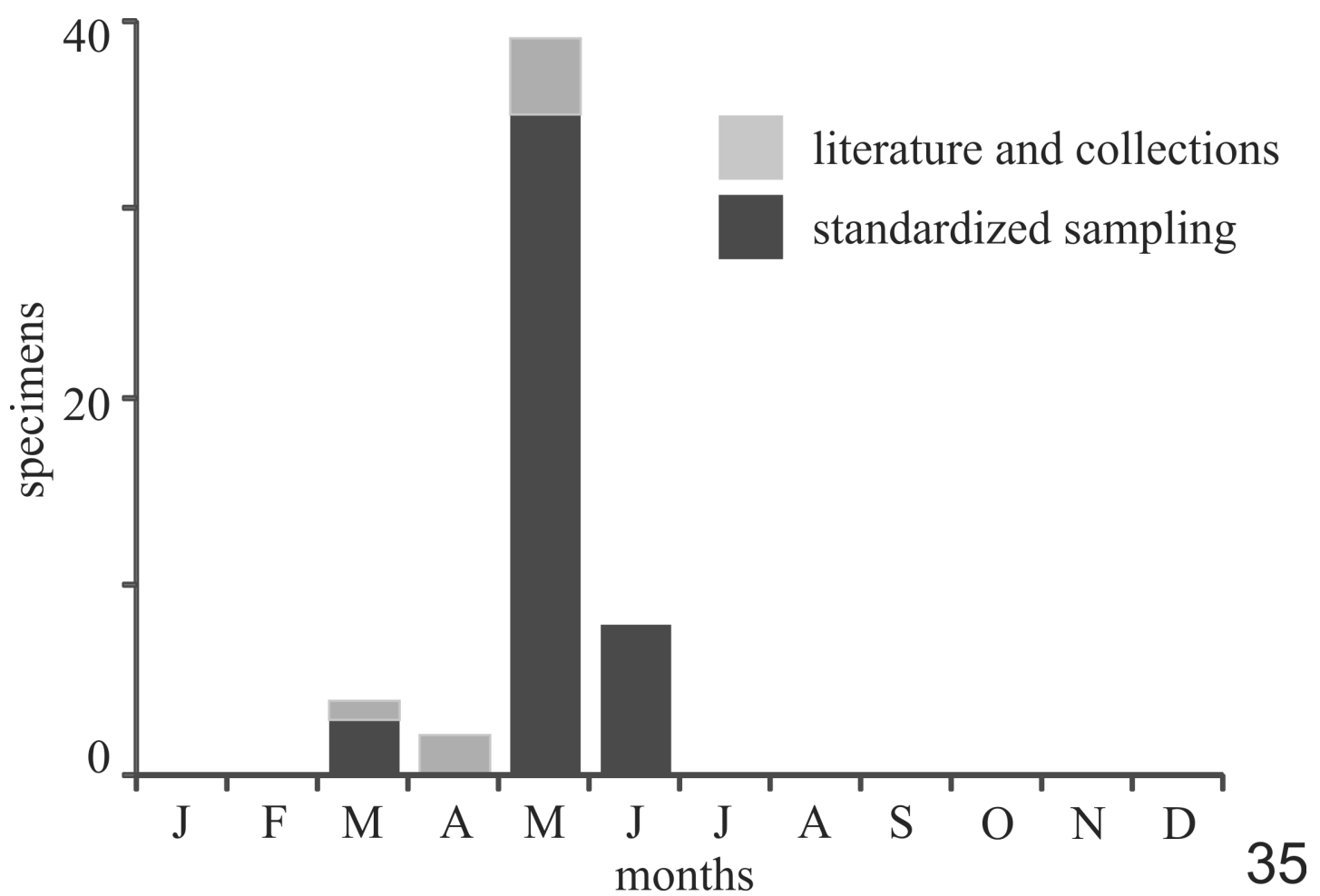

FIGURE 35. Number of known specimens of Feltia carolia (Schaus, 1929) comb. nov. $(\mathrm{n}=53)$ by month of collection, from 1922 to 2014; light gray: records from the literature and specimens in entomological collections; dark gray: specimens collected in light traps from 1998 to 1999 (see text for details).

Spatio-temporal distribution. (Figs 34-35). Forty six specimens of F. carolia comb. nov. were captured in the standardized samplings, in only one of the eleven sampled sites: Lagoa Vermelha, in the Campos de Cima da Serra physiographical zone. In 1998, only four specimens were captured, three in March and one in May; in 1999, 42 specimens were captured, 34 in May and eight in June. Collections were not carried out in June of 1998 and April of 1999 due to heavy rain and low temperatures. Some specimens deposited at the MTCP and listed below in the Material Examined section are voucher specimens of these collections events (e.g. Figs 1-4). Other six known specimens, deposited at the MCTP and CLAM and cited by Specht \& Corseuil (2002), where collected in the same physiographical zone or in its vicinity, in São Francisco de Paula, Centro de Pesquisas e Conservação da Natureza Pró-Mata, $1000 \mathrm{~m}\left(29^{\circ} 28^{\prime} \mathrm{S}\right.$; 50 $\left.50^{\circ} 10^{\prime} \mathrm{W}\right)$, Cambará do Sul, Serra Pousada Estância do Cambará, $980 \mathrm{~m}\left(29^{\circ} 07^{\prime} \mathrm{S}\right.$;

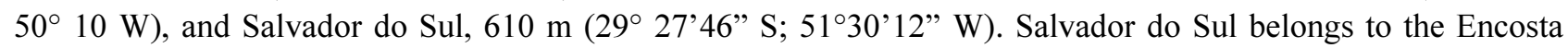
Superior do Nordeste physiographic zone which shares many similarities with the Campos de Cima da Serra in higher elevations (Arend 1990). This site was intensively sampled from 1993 to 2008 by AS but only two male specimens of F. carolia comb. nov. were ever captured, both in a single night of April of 1995. The Campos de Cima da Serra are mountainous plateaus characterized by the presence of mostly native mixed-grasses and woody plants, with gallery forests in the river valleys and mixed ombrophilous montane forests in areas of grater relief. In the vicinity of the collecting site there are some farmlands with annual crops, restricted to areas with greater soil depth. Although Schaus (1929) did not provide a precise type locality for $F$. carolia comb. nov., the type specimen was probably collected in this same physiographical zone, as environments similar to the Campos de Cima da Serra extend greatly northwards, even though discontinuously, throughout the mountainous plateaus in the states of Rio Grande do Sul, Santa Catarina and Paraná (see Fig. 34). Hence, the spatial distribution of F. carolia comb. nov. indicates that this species is endemic to the southern Brazilian Campos (sensu Overbeck et al. 2007) and its surrounding areas (Fig. 34). Feltia carolia comb. nov. appears to be temporally restricted from March to June (Fig. 35), which further suggests that this species has a single generation per year and go through larval (as prepupae) and pupal estival diapauses as observed in other species of Feltia, such as F. brachystria, F. gypaetina (Guenée, 1852) and F. robusta (Blanchard, 1852) (Specht et al. 2004, 2013; Bentancourt \& Scatoni 2006). Both these areas (higher elevation grasslands) and months of the year (autumn and early winter) are usually less attended by 
collectors, which may in part explain the small number or complete absence of specimens of this species in collections.

Type material. Holotype female supposedly deposited at the USNM, collected in March 1922, by Mr. Edward Dukinfield Jones (SI-USNM 2017). The holotype, when and if found, ought to be transferred to the type collection of the USNM and labeled accordingly.

Material Examined. (17 males and 3 females). BRASIL: Rio Grande do Sul, Cambará do Sul (Estância), 34.V.2014, 1 female, Moser leg. (CLAM) (Figs. 5-6), Lagoa Vermelha, 26.III.1998, 2 males, Specht leg., 9534, 15106 [without abdomen], 27.V.1998, 1 male, Specht leg., 9535, 12.VI.1999, 3 males and 1 female, Specht leg., 9538[a], 9538[b]* (Figs 3-4), 9538[c], 9537*, 13.V.1999, 8 males, Specht leg., 9536[a], 9536[b], 9536[c], 9536[d], 9536[e], 9536[f], 9536[g] (Figs 1-2), 9536[h] (MCTP), São Francisco de Paula, 30.V.1996, 3 males, Petersen leg., 4958[a], 4958[b], 4958[c] (MCTP). Santa Catarina, no specific locality, III.1922, 1 female, Dukinfield Jones leg. (USNM) (see comments above).

\section{Acknowledgements}

The authors would like to thank Dr. Paul Goldstein (USNM), Dr. Gervásio Carvalho (MCTP), Dr. Alfred Moser (CLAM), Dr. Marcelo Duarte (MZUSP), Dr. Sonia Lopes (MNRJ), Dr. Alexandre Soares (MNRJ), Dr. Victor Becker (VOB) and Dr. Hubert Thöny (HT) for providing access to the collections under their care; Dr. J. Donald Lafontaine (Canadian National Collection of Insects, Arachnids and Nematodes, Ottawa, Canada) and J. Bolling Sullivan (USNM) for information on the type specimen of Porosagrotis carolia Schaus, 1929 and fruitful discussions; Dr. Hector Vargas and Dr. Aidas Saldaitis for reviewing and editing our manuscript, respectively; Sr. Ricardo Graff for permitting collecting in his propriety, Granja Canarinho, Lagoa Vermelha, Rio Grande do Sul; Conselho Nacional de Desenvolvimento Científico e Tecnológico (CNPq) and Coordenação de Aperfeiçoamento de Pessoal de Nível Superior (Capes) for the fellowship granted to the authors (MMC: 308247/2013-2, CNPq; OHHM: 304639/2014-1, CNPq; AS: 306601/2016-8, CNPq; FMSD: Edital 15/2014, Capes/Embrapa), and the financial support of CNPq (403376/2013-0) and Empresa Brasileira de Pesquisa Agropecuária (Embrapa) (SEG MP2 02.13.14.006.00.00).

\section{References}

Arend, L.M. (1990) Geografia Física. In: Hoffmann, G.R., Arend, L.M., da Silveira, J.C.B., Bellomo, H.R. \& Nunes, L.L.M. (Eds.), Rio Grande do Sul - Aspectos da Geografia. Martins Livreiro, Porto Alegre, pp. $22-53$.

Bentancourt, C.M. \& Scatoni, I.B. (2006) Lepidopteros de importancia económica en Uruguay: reconocimiento, biología y daños de las plagas agrícolas y forestales. Hemisfério Sur, Montevideo, $437 \mathrm{pp}$.

Boisduval, J.B.A.D. \& Guenée, A. (1852) Histoire Naturelle des Insectes. Species Général des Lépidoptères. Tome Cinquième. Noctuélites. Tome 1. Roret, Paris, 407 pp.

Frost, S.W. (1957) The Pennsylvania Insect Light Trap. Journal of Economic Entomology, 50, 287-292. https://doi.org/10.1093/jee/50.3.287

Fabricius, O. (1794) Bidrag til Snylte-Ormenes Historie. Skrivter af Naturhistorie-Selskabet, 3, 1-45.

Grote, A.R. \& Robinson, C.T. (1868) Descriptions of American Lepidoptera. № 3. Transactions of the American Entomological Society, 1, 323-360.

Hampson, G.F. (1903) Catalogue of the Lepidoptera Phalaenae in the British Museum, Volume 4. Taylor and Francis, London, $689 \mathrm{pp}$.

Hübner, J. (1816-[1825]) Verzeichniss bekannter Schmettlinge [sic]. Jacob Hübner, Augsburg, 431 pp.

Lafontaine, J.D. (2004) The Moths of America North of Mexico. Fascicle 27.1: Noctuidae (part) - Agrotini. The Wedge Entomological Research Foundation, Washington, D.C., 385 pp.

Lafontaine, J.D. \& Fibiger, M. (2004) Classification and distribution of the Agrotini. In: Lafontaine, J.D. (Ed.), The Moths of America North of Mexico. Fascicle 27.1: Noctuidae (part) - Agrotini. The Wedge Entomological Research Foundation, Washington, D.C., pp. 17-24.

Ochsenheimer, F. (1816) Die Schmetterlinge von Europa. Vol. 4. Gerhard Fleischer, Leipzig, 224 pp.

Orlandin, E., Favretto, M.A., Piovesan, M. \& Santos, E.B. (2016) Borboletas e Mariposas de Santa Catarina: uma introdução. Mario Arthur Favretto, Campos Novos, 213 pp.

Overbeck, G.E., Müller, S.C., Fidelis, A., Pfadenhauer, J., Pillar, V.D., Blanco, C.C., Boldrini, I.I., Both, R. \& Forneck, E.D. (2007) Brazil's neglected biome: The South Brazilian Campos. Perspectives in Plant Ecology, Evolution and Systematics, 
9, 101-116.

https://doi.org/10.1016/j.ppees.2007.07.005

Piovesan, M., Orlandin, E., Favretto, M.A. \& Santos, E.B. (2014) Contribuição para o conhecimento da Lepidopterofauna de Santa Catarina. Scientia Plena, 10, 1-32.

Poole, R.W. (1989) Noctuidae. In: Heppner J.B. (Ed.), Lepidopterorum Catalogus (New Series) Fascicle 118. Noctuidae. Parts 1-3. Brill, New York, $1314 \mathrm{pp}$.

San Blas, G. (2014) Agrotis Ochsenheimer (Lepidoptera, Noctuidae): a systematic analysis of South American species. Zootaxa, 3771, 1-64. https://doi.org/10.11646/zootaxa.3771.1.1

San Blas, G. (2015) A morphological phylogeny of Agrotis Ochsenheimer (Lepidoptera, Noctuidae), with emphasis on the South American species. Zoologica Scripta, 44, 153-164. https://doi.org/10.1111/zsc.12091

Schaus, W. (1923) Galapagos Heterocera with descriptions of new species. Zoologica, 5, 23-48.

Schaus, W. (1929) New species of Heterocera (Lepidoptera) from southern Brazil. Procceedings of the entomological Society of Washington, 31, 45-56

Shorthouse, D.P. (2010) SimpleMappr, an online tool to produce publication-quality point maps. Available from: http:// www.simplemappr.net (accessed 5 July 2017)

SI-USNM-Smithsonian Institution, United States National Museum (2017) Search the Department of Entomology Collections. Porosagrotis carolia Schaus: Noctuidae: Lepidoptera: Insecta: Arthropoda. Available from: http://n2t.net/ ark:/65665/3bb20a804-f1f5-477e-a49b-cb8ca66de71c (accessed 5 July 2017)

Smith, J.B. (1890) Contributions to a Monograph of the Insects of the Lepidopterous Family Noctuidae of Temperate North America. Revision of the Species of the Genus Agrotis. Bulletin of the United States National Museum, 38, 1-237. https://doi.org/10.5479/si.03629236.38.i

Specht, A. \& Corseuil, E. (2002) Diversidade dos noctuídeos (Lepidoptera, Noctuidae) em Salvador do Sul, Rio Grande do Sul, Brasil. Revista Brasileira de Zoologia, 19, 281-298. https://doi.org/10.1590/S0101-81752002000500022

Specht, A., Silva, E.J.E. \& Link, D. (2004) Noctuídeos (Lepidoptera, Noctuidae) do Museu Entomológico Ceslau Biezanko, Faculdade de Agronomia "Eliseu Maciel”, Universidade Federal de Pelotas, RS. Revista Brasileira de Agrociência, 10, 389-409.

Specht, A., Angulo, A.O., Olivares, T.S., Fronza, E., Roque-Specht, V.F., Valduga, E., Albrecht, F., Poletto, G. \& Barros, N.M. (2013) Life cycle of Agrotis malefida (Lepidoptera: Noctuidae): a diapausing cutworm. Zoologia, 30, 371-378. https://doi.org/10.1590/S1984-46702013000400002

Walker, F. (1856) List of the Specimens of Lepidopterous Insects in the Collection of the British Museum. Vol. 9. Edward Newman, London, 252 pp. 